\title{
Quality And Effectiveness Of Enterprise Resource Planning - Customer Relationship Management Systems: Implications For Information Systems Marketing Strategies \\ Leonidas Hatzithomas, (E-mail: leonidasnoe@yahoo.com), Aristotle University of Thessaloniki, Greece Ioannis Stamelos, (E-mail: stamelos@csd.auth.gr), Aristotle University of Thessaloniki, Greece Thomas Fotiadis, (E-mail: fotiadis@uom.gr), University of Macedonia, Greece John Mylonakis, (E-mail: imylonakis@panafonet.gr), Greece
}

\begin{abstract}
The present research examines the success of Enterprise Resource Planning (ERP) systems in Greece, employing Delone and McLean's model. The questionnaires of the study were e-mailed to the 1,049 largest organizations based on turnover and assets. The final research sample consists of 105 Greek enterprises. The list of organizations was compiled by using the Index of Companies and Products Directory (ICAP). Results show that users have more positive attitude towards system quality and information quality and less positive attitude towards service quality. Moreover, users believe that ERP systems enhance their performance and can contribute to the control of management. Furthermore, present paper proved that D\&M model constitutes a causal model with the exception of the variable of system use that is only related to user satisfaction, and ERP system quality. The findings of this research trigger many theoretical and managerial implications and create lots of potential for future research in the fields of Information Systems, Management, and Marketing.
\end{abstract}

\section{INTRODUCTION}

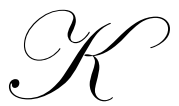

umar and Van Hillegersberg (2000) defined Enterprise Resource Planning (ERP) systems as configurable information system packages that integrate information and information based processes within and across functional areas in an organization. Customer Relationship Management (CRM) systems are defined as an all - embracing approach, which seamlessly integrates sales, customer service, marketing, field support and other functions that touch customers (Xu et al., 2002). Most times CRM systems are considered modules of ERP systems (Samoladas et al. 2003). The present research paper deals with them as such.

ERP systems offer a holistic approach to enterprises with one single and reliable interface for the whole system (Klaus et al. 2000). However, the implementation of an ERP in an enterprise includes high cost installation and maintenance, while one should not overlook the probability to fail, resulting thus in painful consequences for the enterprise, as for example - the probability of leading the enterprise to bankruptcy (Davenport, 1998; Markus et al, 2000). The present results from the fact that ERP systems instil their own logic, strategy, organisation and culture in the enterprises (Davenport, 1998; Lee and Lee, 2000) calling them to adapt by following the best organizational practices that ERP systems express (Kremers and Dissel, 2000). It is acknowledged that $90 \%$ of ERP system applications delay or exceed the initial budget and the degree of success of applications in the enterprises is limited to $33 \%$ (Zhang, 2002).

Davenport suggests that while the rise of the Internet has received most of the media attention in recent years, the business world's embrace of enterprise systems, namely the Enterprise Resource Planning systems, may in fact be the most important development in the corporate use of information technology in the 1990s. Davenport's opinion 
reveals the high expectations that have emerged by the advent of Enterprise Resource Planning systems. However, everyday practice indicates that there are many problems with the implementation of ERP systems. Factors affecting ERP systems implementation are complex and abundant, and menace ERP's success.

Through the review of the literature and bibliography, emerge a number of characteristics that can influence the success of information systems. Delone and McLean (1992, 2003) have carried out the most important contribution to this sector. In their effort to create a single approach to the thorny question of what is defined as success of information systems, they divided the factors of success that had resulted from prior studies, into six basic groups.

In Delone and McLean's first study (1992), the six basic groups of information systems' factors of success are System Quality, Information Quality, Use, User Satisfaction, Individual Impact and Organizational Impact. In a later approach of the initial model (Delone and McLean, 2003), Service Quality was added, while the Individual Impact and the Organizational Impact were replaced by the more general term Net Benefits (benefits for the employees, the enterprises and the whole society and economy, Figure 1).

The purpose of the present paper is twofold: First, it aims to study the level of success of ERP systems in the largest Greek enterprises, based on Delone and McLean's model (2003). In order for the research to be conducted, the 1,500 largest Greek enterprises were targeted (based on their assets and turnover, as they result from the ICAP, 2004). More specifically, regarding the key users of ERP systems of the largest Greek enterprises, the following research questions arise:

(a) Do they consider the quality of systems high?

(b) Do they use them extensively?

(c) Are they satisfied with their performance?

(d) Do they believe that ERP systems can help them increase their personal productivity?

(e) Do they consider that ERP systems help their enterprise to control management?

Secondly, the present paper examines whether Delone and McLean's model constitutes a causal model or just a process model.

\section{LITERATURE REVIEW}

\section{First Research Question}

The main research factors will be defined below: ERP systems quality, ERP systems information quality, ERP systems services quality, user satisfaction, usage of ERP systems and Net Benefits. To define the main research factors means to select the appropriate measures that will represent and express these general factors.

\section{ERP Systems Quality}

System quality is a measure of quality for the systems themselves (Negash et al. 2002). The choice of definition of system quality in the prior studies was based on characteristics of systems that were studied. In line with prior studies, a definition of system quality will be proposed based on the specific characteristics of ERP systems.

ERP systems are interwoven with the capability of integration of all individual information systems of an enterprise in a unique and unified system that uses a central database (CMU, 1998; Kumar et al., 2000; Laudon and Laudon 2001; Shehab et al., 2004). The integration of single organizational operations in a complete system is the basic reason of the growth of ERP systems and consequently it is important to constitute one measure of ERP systems quality. Indeed, according to Bingi et al. (1999), one of the most important elements that influence the implementation of ERP systems is their ability to integrate. Sprott (2000) proposed the integration of ERP systems as a factor of their purchase. Shehab et al. (2004) considered the weakness of ERP systems to collaborate with other information systems (that are not ERP) as ERP's basic disadvantage. Moreover, Sandoe et al (2001) determined a group of tangible and 
intangible advantages that arise from the integration of information systems, an integration that can be achieved through the use of ERP systems. For the above reasons, the first measure that is used for the measurement of system quality is system integration.

Everdingen et al. (2000) stressed the importance of usability of ERP systems after research in small to medium-sized enterprises. Indeed, a hard to use system can even lead the enterprise to bankruptcy (Davenport, 1998; Markus et al, 2000). Shehab et al. (2004, p. 368), referring to the disadvantages of ERP systems, underlined the lack of usability, since the ERP's learning curve is too high, they are not user-friendly to occasional users, system input is not always logical (intuitive), ability to cut-and-paste and online help capability are hard to use and report terminology and the accounting rules are difficult to understand.

ERP systems are systems that cover the total of enterprises (CMU, 1998; Kumar et al, 2000; Laudon and Laudon 2001; Shehab et al, 2004). Consequently, it is crucial for ERP systems to be reliable, since a short - time interruption of company activities can lead the enterprise to big damages and can spot its credibility.

The integration, the easy of use and the reliability of the ERP systems are the three dimensions via which the systems' quality is defined. Delone and McLean (1992) also proposed these three dimensions as suitable for this aim.

\section{ERP Systems Information Quality}

Delone and McLean (1992) propose the variables of content and timeliness of systems information as criteria for the evaluation of systems information quality. Moreover, the literature review reveals that a lot of researchers have handled the variable of timeliness (Bailey and Pearson, 1983; King and Epstein, 1983; Srinivasan, 1985; Kahn et al, 2002), but also that of accuracy (Bailey and Pearson, 1983) and relevancy (Bailey and Pearson, 1983; Miller and Doyle, 1987; Srinivasan, 1985). Accuracy and relevancy are included in present study as elements of information content, in order to define the quality of information.

Therefore, the dimensions that depict the quality of information in the present research will be the content of information (that includes questions relative to the accuracy and clarity of information) and the timeliness of information (for instance "Do you get the information you need in time?").

\section{ERP Systems Service Quality}

For the study of service quality, information system researchers have mainly used the SERVQUAL model. SERVQUAL arises from literature of Marketing and was developed by Parasuraman et al. (1988). Parasuraman et al. (1988), after applying the factor analysis to the variables they had collected for the services quality in 1985, they ultimately defined five dimensions that measure the quality of services. Parasuraman et al. improved the model in 1991, while a lot of researchers extended it (Kang and James, 2004, Caruana and Pitt, 1997). The SERVQUAL model is composed of five dimensions: reliability, assurance, tangibles, empathy, and responsiveness.

Pitt et al. (1995) examined whether SERVQUAL can be applied to study information systems service quality and found out that it is indeed applicable. After Pitt et al's (1995) research, a lot of authors used SERVQUAL to define and study quality of the services supplied by an information services provider (Negash et al., 2003). Delone and McLean (2003) in particular, encouraged the use of the three out of the five dimensions that compose SERVQUAL (assurance, responsiveness, and empathy) for the study of quality of services that is offered in the electronic commerce. This fact indicates the great importance of the model in the sector of information systems but also its appropriateness for the definition of information system success.

\section{ERP Systems Satisfaction}

The factor of user satisfaction from the information systems has been measured using many different ways. Baroudi and Orlikowski (1988) described user satisfaction by three basic factors: (1) information system, (2) personnel and services and (3) knowledge and involvement. Bailey and Pearson (1983) suggested 36 factors that may 
influence in some way user satisfaction. It is evident that the aforementioned definitions are too general to be used for the correlation of users satisfaction with other factors. This happens because they apply common variables with other factors (for example, Bailey and Pearson's definition uses the variable "system reliability" which is also used for the measurement of system quality) and it is reasonable to be finally correlated.

Indeed a lot of researchers have employed user satisfaction in order to totally define the success of information systems with one and unique variable (Yoon et al., 1995). Negash et al. (2003) preferred to describe user satisfaction using the variable of overall satisfaction that has been the result of two items (for example, my overall satisfaction level with regard to the ERP support interface I use is better than what I expected). The Negash et al. (2003) approach was adopted in the present research (Table 1).

\section{Usage of ERP Systems}

Most researchers have approached the use of information systems from the aspect of frequency of use (Culnan, 1983; Kim and Lee, 1986; Raymond, 1985; Srinivasan, 1985). In fact, in a plethora of studies, the use of information systems was defined by variables relative to the frequency of use, such as the frequency of prior use, the frequency of intended use (Ein - Dor et al, 1981), the frequency of general use, the frequency of special use (Fuerst and Cheney, 1982) and the frequency of voluntary use (Hogue, 1987). In the present research, for the study of use of ERP systems the variable of frequency of use is employed.

\section{ERP Systems Net Benefits}

Net Benefits in Delone and McLean's second model (2003) replaced the two single factors of individual impact and organizational impact, so that they express a wider field of benefits from information systems. ERP systems in the present paper will not be studied with regard to their effect on the total of society. Consequently, Net Benefits will be defined with the dimensions of individual and organizational impact, similarly to Delone and McLean's (1992) first model.

One of the basic reasons for the development of ERP systems during the latest years is the managerial changes that befell the modern enterprises that required the implementation of more sophisticated management (Klaus et al, 2000).

The managerial changes that launched the birth of ERP systems were the following: "the recognition of "best practices', the one view of the customer, larger and more complex organizations, flat, flexible, adaptive organizational designs, the continuing desire for improved managerial decision making, the need to respond rapidly to the changing marketplace, the need to integrate across functions for competitive success, the Supply Chain Management and the need for integration to support Customer Relationship Management" (Klaus et al, 2000, p. 155). Indeed ERP systems are, by definition, systems that aim at enforcing the management of enterprises through the integration of their operations (Shehab et al., 2004). Based on the above, the variable of management control is used in order to express the net benefits, and more specifically the organizational impact.

Torkzadeh and Doll (1999), describing the effect of information systems on the work of employees, proposed productivity and innovation as the most influential factors, regarding the duties of employees, the satisfaction of customers and the management control (variable which will be used for the definition of organizational impact). Concerning the duties of employees, productivity was also used in other published works in order to describe the individual benefits of information systems, as in the research of Gueutal et al. (1984) on students of MBA for information systems, and in the study of Rivard and Huff (1984), on users of information systems in 10 enterprises. Delone and McLean (1992) also put forward the use of individual productivity as a measure for the expression of individual effects. Following the example of the aforementioned researchers, in the present research the productivity of employees will be used in order to define the individual and the net benefits of ERP systems. 
To sum up, in order to measure the dimensions of management control (for example, "ERP improves management control") and the individual productivity (for example, "ERP increases my productivity"), the measures that Torkzadeh and Doll developed in 1998 were used (Table 1).

\section{Second Research Question}

The success groups of the D\&M model, according to Delone and McLean (2003), do not just represent a succession of situations (process model); they have a cause and effect relationship (causal model). Therefore, user satisfaction and usage of ERP system are the result of ERP system quality, ERP information quality and ERP services quality, while usage of system and user satisfaction affect individual impact and organizational impact (Net Benefits). Seddon (1997), after years of study on the D\&M model, has reached the conclusion that it cannot be both a process and a causal model. However, Seddon (1997) proposed two causal models which, according to Delone and McLean (2003), make the initial D\&M model in fact more complex, driving it away from its initial aim.

As has been alleged by some studies and proven by research, the quality of information systems is related to user satisfaction. In particular, Negash et al. (2003) have proven that the quality of Web-based customer support systems is directly correlated with user satisfaction. In the same vein, Seddon \& Kiew (1994) have shown that the quality of information systems exerts a direct effect on user satisfaction, while Mahmood et al. (2000) indicated that the "easy of use" is positively correlated with user satisfaction.

Second, information quality is considered to be one of the key-factors affecting user satisfaction (Ditsa \& McGregor, 1996, cited from Mahmood et al., 2000). Moreover, the research of Negash et al. (2003) has shown that the quality of Web-based customer support systems is positively correlated with user satisfaction. Seddon \& Kiew (1994) have also reached to the same conclusion.

Third, Jun et al. (2004) have studied the quality variables of packaged software products and concluded that system service quality is positively correlated with user satisfaction, as well as the user's perception of overall system quality. The Yang \& Fang (2004) study, conducted using the content analysis method, showed that the most dimensions of services quality are related positively to user satisfaction. The following hypothesis is formulated:

H1: The perceived by the user (a) ERP system quality, (b) ERP system information quality and (c) ERP system service quality are positively correlated with user satisfaction.

Taylor \& Todd (1995) and Igbaria et al. (1995b), studying the effect of information quality on usage of the systems, inferred that high information quality leads to higher usage. Moreover, it has been observed that when an information system appears to produce inaccurate information, its usage is reduced (Strong, 1997). More specifically, for ERP systems aiming at integrating all enterprise data and information into a central database accessed by all employees (Shehab et al., 2004; Martin, 1998), it is important that information is accurate, clear and up-to-date. On the contrary, employees will continue to use the older system, which better meets their needs. This results in delays in the application of the ERP system or even in the failure of the project. As a result of the above analysis, the following hypothesis rises:

$\mathrm{H} 2$ : The perceived by the user (a) ERP system quality, (b) ERP system information quality and (c) ERP system service quality are positively correlated with the usage of the ERP system.

The "usage of information system" and "user satisfaction" elements have been studied by several researchers, in order to comprehend the relationship that exists between them. The results have shown their positive correlation (Igbaria \& Tan, 1997; Torkzadeh \& Doll, 1999; Gelderman, 1998), a fact that validates the Delone \& McLean (1992) theoretical model. Thus the following hypothesis emerges:

H3: The user satisfaction is positively correlated with the usage of the ERP systems. 
A number of researchers (Goodhue \& Thompson, 1995; Teng \& Calhoun, 1996; Igbaria \& Tan, 1995; Guimaraes \& Igbaria, 1997; Yuthas \& Young, 1998; Torkzadeh \& Doll, 1999) have reached to the conclusion that the usage of information systems causes Net Benefits. Particularly the adoption of ERP systems leads to a plethora of tangible and intangible benefits, since these are considered as necessary for organizational performance business sustainability (Markus et al., 2000). Potential benefits include a noticeable drop in the number of warehouse inventories, fewer constraints in working capital management, abundance of information regarding customer needs and preferences and the possibility for integrated management of suppliers, associates, employees and customers (Chen, 2001). Furthermore, some of the tangible benefits resulting from ERP systems are the reduction of program implementation time, the loading and unloading within scheduled timeline, the increase of turnover and less work in progress. Intangible benefits resulting from ERP usage include customer satisfaction, increased effectiveness, increased elasticity, reduced cost for the production of quality products, better usage of resources, improved quality of information content and better decision-making ability (Siriginidi, 2000). Based on relevant literature, it is evident that the usage of ERP systems produces individual and organizational benefits. The following hypothesis is formulated:

H4: The use of ERP systems is positively correlated with Net Benefits.

Apart from the "usage of information systems" variable, a number of studies has shown that the "information systems satisfaction" variable is related to individual benefits (Igbaria \& Tan, 1995; Guimaraes \& Igbaria, 1997; Yuthas \& Young, 1998; Torkzadeh \& Doll, 1999; Seddon \& Kiew, 1994) and organizational benefits (Gelderman, 1998). As a result of the above analysis, the following hypothesis rises:

H5: The satisfaction from using ERP systems is positively correlated with Net Benefits.

\section{RESEARCH METHODOLOGY}

Table 1 presents the instruments that were selected for the measurement of five factors: ERP Systems Quality, ERP Systems Information Quality, ERP Systems Service Quality, ERP Systems Usage, and ERP Systems Net Benefits.

Table 1: Measures

\begin{tabular}{|c|c|c|}
\hline Measures & Dimensions & Items \\
\hline \multirow{3}{*}{ 1. System Quality } & a. Reliability (Goodhue and Thompson, 1995) & 3 \\
\hline & b. Easy of use ( Davis, 1989) & 4 \\
\hline & c. Integration & 2 \\
\hline \multirow{3}{*}{$\begin{array}{l}\text { 2. Information Quality } \\
\text { (Doll and Torkzadeh, } \\
\text { 1988) }\end{array}$} & a. Timeliness & 2 \\
\hline & b. Content & 3 \\
\hline & a. Tangibles & 3 \\
\hline \multirow{4}{*}{$\begin{array}{l}\text { 3. Service Quality (Pitt } \\
\text { et al., 1995) }\end{array}$} & b. Reliability & 3 \\
\hline & c. Responsiveness & 3 \\
\hline & d. Assurance & 3 \\
\hline & e. Empathy & 3 \\
\hline $\begin{array}{l}\text { 4. Satisfaction (Negash } \\
\text { et al., 2003) }\end{array}$ & a. User satisfaction & 2 \\
\hline \multirow{2}{*}{ 5. Net Benefits } & a. Individual Productivity (Torkzadeh and Doll, 1998) & 3 \\
\hline & b. Management Control (Torkzadeh and Doll, 1998) & 3 \\
\hline
\end{tabular}

\section{Sample}

It is known, that ERP is designed for large firms (Shehab et al., 2004). Thus, for the conduct of the research in Greek enterprises, the 1,500 largest Greek enterprises were selected, based on the criteria of turnover and assets. The enterprises were determined with the help of databases of the research company ICAP, which allows the 
completion of the search with the use of two criteria of choice. Next, the electronic mail addresses of enterprises were requested, a process which decreased the target sample since many addresses were not open to the wide public. Finally, 1,049 e-mails were sent with attached questionnaires, instructed to be answered by "key users" of enterprise's ERP systems. The final sample of enterprises that responded to the questionnaires was 105 enterprises, a sample that represents response rate of $10 \%$.

Through the study of Table 2, it is easily made clear that the users of the sample enterprises are exceptionally experienced, since sixty one of them handle the ERP system almost during all day and most of them (eighty seven) at least one to four times a day. With regard to the position of respondents, it emerges that they are mainly managers, while no one is a "worker" in the production or the service of customers.

Table 2: Users

\begin{tabular}{|c|c|c|c|}
\hline & Count & Percent $(\%)$ & Valid Percent $(\%)$ \\
\hline Number of Respondents & 105 & 100 & 100 \\
\hline Position in the Company: & 97 & 92.4 & 100 \\
\hline Manager & 79 & 75.2 & 81.4 \\
\hline Knowledge worker (e.g. civil engineers, architects) & 11 & 10.5 & 11.3 \\
\hline Data workers (e.g. secretaries, accountants) & 7 & 6.7 & 7.2 \\
\hline Production and service worker (e.g. packer and machinist) & 0 & 0 & 0 \\
\hline Frequency of use: & 102 & 97.1 & 100 \\
\hline Once a month & 3 & 2.9 & 2.9 \\
\hline Once a week & 3 & 2.9 & 2.9 \\
\hline 2-5 times a week & 9 & 8.6 & 8.8 \\
\hline 1-4 times a day & 16 & 15.2 & 15.7 \\
\hline 5-8 times a day & 6 & 5.7 & 5.7 \\
\hline 9 times a day & 4 & 3.8 & 3.9 \\
\hline All the time & 61 & 58.1 & 59.8 \\
\hline
\end{tabular}

The companies that constitute the sample are mainly enterprises that at the same time act as Business to Business (B2B) and as Business to Consumer (B2C) enterprises (44.1\%). However, many characterize themselves as Business to Business only (41.4\%), while the largest percentage of enterprises (55.4\%) participates in the productive process (Table 3).

The economic elements of the sample enterprises (Table 3) are presented high enough (it is reasonable because it constituted the criterion for their choice); their turnover oscillates mainly between 10 and 50 million Euros (58.57) and the total of their assets is between 10 and 50 million Euros. It is interesting that some enterprises whose turnover and asset exceed 300 million Euros ( 2 and 3 enterprises respectively) took part in the research.

With regard to the enterprise's number of employees (Table 3), it appears that $37.3 \%$ of the enterprises occupy more that 250 workers. It is also estimated as very important the fact that the enterprises are not located exclusively in the region of Attica (52.9\%), but come from other regions as well, such as Thessaly (5.7\%).

Concerning the use of ERP systems (Table 4), it appears that the Logicdis Company (24\%) possesses the reins together with SAP (18.8\%), which is in the second place of the table. The system of the company Atlantis appears to be used by the $11.5 \%$ of the sample and the corresponding ERP of Singular by the $9.4 \%$. 
Table 3: Enterprises

\begin{tabular}{|c|c|c|c|}
\hline & Count & Percent $(\%)$ & Valid Percent $(\%)$ \\
\hline Number of Respondents & 105 & 100 & 100 \\
\hline Type of firm: & 99 & 94.3 & 100 \\
\hline Business to Business & 41 & 39.0 & 41.4 \\
\hline Business to Consumer & 14 & 13.3 & 14.1 \\
\hline Business to Business and Business to Consumer & 44 & 41.9 & 44.4 \\
\hline Type of firm: & 74 & 70.5 & 100 \\
\hline Manufacturing & 26 & 24.8 & 35.1 \\
\hline Wholesale & 17 & 16.2 & 23 \\
\hline \multicolumn{4}{|l|}{ Retailing } \\
\hline Services & 6 & 5.7 & 8.1 \\
\hline Manufacturing and Wholesale & 11 & 10.5 & 14.9 \\
\hline Wholesale and Retailing & 7 & 6.7 & 9.6 \\
\hline Manufacturing, Wholesale and Retailing & 3 & 2.8 & 4 \\
\hline Manufacturing, Wholesale and Services & 1 & 0.95 & 0.3 \\
\hline Wholesale and Services & 2 & 1.9 & 2.7 \\
\hline Wholesale, Retailing and Services & 1 & 0.95 & 0.3 \\
\hline Turnover: & 70 & 66.6 & 100 \\
\hline Bellow 10 million $€$ & 8 & 7.6 & 11.4 \\
\hline $10-50$ million $€$ & 41 & 39 & 58.57 \\
\hline $50-100$ million $€$ & 14 & 13.32 & 20 \\
\hline $100-150$ million $€$ & 3 & 2.9 & 4.3 \\
\hline $150-300$ million $€$ & 2 & 1.9 & 2.9 \\
\hline More than 300 million $€$ & 2 & 1.9 & 2.9 \\
\hline Assets: & 68 & 64.8 & 100 \\
\hline Bellow 10 million $€$ & 13 & 12.4 & 19 \\
\hline $10-50$ million $€$ & 36 & 34.3 & 53 \\
\hline $50-100$ million $€$ & 8 & 7.62 & 11.8 \\
\hline $100-150$ million $€$ & 3 & 2.85 & 4.4 \\
\hline $150-300$ million $€$ & 5 & 4.76 & 7.4 \\
\hline More than 300 million $€$ & 3 & 2.85 & 4.4 \\
\hline
\end{tabular}

Regarding the modules of the ERP systems that the Greek enterprises use (Table 4), these are focused mainly on the regulation of daily bureaucracy (inventory $94.3 \%$, purchasing $93.3 \%$, payables/ billing $89.5 \%$, sales analysis $88.6 \%$, cost accounting $88.6 \%$ and order entry $86.7 \%$ ) and to a lesser extent on specialized company operations (personnel $37.1 \%$ and forecasting $47.6 \%$ ).

Most enterprises possess the ERP systems for an important period of time (62.8\% above 25 months and $35.2 \%$ above 4 years), a fact that places them in the post-implementation phase of the system (Table 5). In any case, fifteen enterprises are found at a very early stage regarding the application of ERP system to them (they use the system less than 6 months).

The existence of problems in the implementation of ERP systems is a rule (87\%). Nevertheless, the cases in which the problems are considered very serious (3.4\%) or the most serious (3.4\%) are few. 
Table 4: ERP Systems

\begin{tabular}{|c|c|c|c|}
\hline & Count & Percent $(\%)$ & Valid Percent (\%) \\
\hline Number of Respondents & 105 & 100 & 100 \\
\hline Enterprise's primary ERP software provider: & 96 & 91 & 100 \\
\hline Logicdis & 23 & 21.9 & 24.0 \\
\hline Sap & 18 & 17.1 & 18.8 \\
\hline Atlantis & 11 & 10.5 & 11.5 \\
\hline Singular (Sen Enterprise) & 9 & 8.6 & 9.4 \\
\hline Logismos (Momentum) & 5 & 4.8 & 5.2 \\
\hline Oracle & 3 & 2.9 & 3.1 \\
\hline Microsoft Navision & 3 & 2.9 & 3.1 \\
\hline Orama & 3 & 2.9 & 3.1 \\
\hline Panorama (Softone) & 3 & 2.9 & 3.1 \\
\hline Custom & 3 & 2.9 & 3.1 \\
\hline Bbcs & 2 & 1.9 & 2.1 \\
\hline Dcw Software & 2 & 1.9 & 2.1 \\
\hline Megatron & 1 & 1.0 & 1.0 \\
\hline As 400 & 1 & 1.0 & 1.0 \\
\hline Betolink Enterprise & 1 & 1.0 & 1.0 \\
\hline E-Festos & 1 & 1.0 & 1.0 \\
\hline Emphasis Fasion & 1 & 1.0 & 1.0 \\
\hline Epicor & 1 & 1.0 & 1.0 \\
\hline Finis (Fourlis In House Information System) & 1 & 1.0 & 1.0 \\
\hline Inhouse & 1 & 1.0 & 1.0 \\
\hline Lavisoft Ermis & 1 & 1.0 & 1.0 \\
\hline Power Objects & 1 & 1.0 & 1.0 \\
\hline Syntech Fortune & 1 & 1.0 & 1.0 \\
\hline ERP Modules: & 105 & 100 & 100 \\
\hline Payroll/ Receivables & 47 & 44.8 & 44.8 \\
\hline General Ledger & 58 & 55.2 & 55.2 \\
\hline Inventory & 99 & 94.3 & 94.3 \\
\hline Forecasting & 50 & 47.6 & 47.6 \\
\hline Personnel & 39 & 37.1 & 37.1 \\
\hline Purchasing & 98 & 93.3 & 93.3 \\
\hline Word Processing & 15 & 14.3 & 14.3 \\
\hline Payables/ Billing & 94 & 89.5 & 89.5 \\
\hline Sales Analysis & 93 & 88.6 & 88.6 \\
\hline Cost Accounting & 93 & 88.6 & 88.6 \\
\hline Budgeting & 77 & 73.3 & 73.3 \\
\hline Order Entry & 91 & 86.7 & 86.7 \\
\hline Production Scheduling & 45 & 42.9 & 42.9 \\
\hline Production Control & 45 & 42.9 & 42.9 \\
\hline Type of ERP systems: & 100 & 100 & 100 \\
\hline Open Source & 0 & 0 & 0 \\
\hline Closed Source & 100 & 100 & 100 \\
\hline
\end{tabular}


Table 5: ERP Systems

\begin{tabular}{|c|c|c|c|}
\hline & Count & Percent $(\%)$ & Valid Percent (\%) \\
\hline Number of Respondents & 105 & 100 & 100 \\
\hline How long does company operate the ERP system? & 105 & 100 & 100 \\
\hline Bellow 6 months & 15 & 14.3 & 14.3 \\
\hline 7 months to 1 year & 3 & 2.9 & 2.9 \\
\hline 13 months to 2 years & 21 & 20.0 & 20.0 \\
\hline 25 months to 4 years & 29 & 27.6 & 27.6 \\
\hline 4 years and more & 37 & 35.2 & 35.2 \\
\hline Did the company encounter any problems with ERP system & 100 & 95.2 & 100 \\
\hline & 32 & 30.5 & 32 \\
\hline No & 68 & 64.8 & 68 \\
\hline Yes & & & \\
\hline $\begin{array}{l}\text { If the company encountered problems with ERP system } \\
\text { operation, which is the importance of these problems? These } \\
\text { problems were of: }\end{array}$ & 87 & 82.9 & 100 \\
\hline Very little importance & 14 & 13.3 & 16.1 \\
\hline Little importance & 46 & 43.8 & 52.9 \\
\hline Moderate importance & 21 & 20.0 & 24.1 \\
\hline Great importance & 3 & 2.9 & 3.4 \\
\hline Huge importance & 3 & 2.9 & 3.4 \\
\hline
\end{tabular}

\section{RESEARCH RESULTS}

\section{First Research Question}

Tables 6 to 11 enumerate the descriptive statistics of all questions of the questionnaire that concern the internal factors of success of ERP systems (ERP Systems Quality, Information Quality, Service Quality, Satisfaction and Net Benefits, that is, individual impact and organizational impact).

The general observation that results from the examination of the tables is that users seem to be satisfied as much by the quality of ERP systems as by the quality of information, the service quality and the contribution of systems in individual productivity and in management control. In general, they can be characterized as completely satisfied with the ERP systems they use. However, their answers are not equally positive for all factors and present interesting fluctuations. It is evident that users express more positive opinions of ERP systems information quality (Table 7), of systems quality (Table 6), and less positive of their total satisfaction (Table 9) and of service quality (Table 8). As regards the net benefits (Tables $10 \& 11$ ), the users' attitudes compared to the remainder of the answers can be characterized as mediocre tending to become positive.

Based on the research results, the quality of ERP systems appears to constitute one of the most basic weapons the enterprises hide in their "quiver" (Table 6). The answers of the users are exceptionally positive in all the questions that concern reliability, usability and integration. The reliability, in particular, of the ERP systems that the enterprises of the sample use, is presented to be very high (average amount of positive responses $75.3 \%$ and of negatives $9 \%$ ).

The results show that ERP systems quality of information is the factor of success that assembles most positive answers (Table 7). Users consider that their expectations, regarding the ERP systems quality of information, were surpassed in the most positive way, since ERP systems appear to provide accurate (82.7\%), clear (78.9\%) and up-to-date information (80.7\%). 


\section{Table 6: ERP Systems Quality}

\begin{tabular}{|c|c|c|c|c|c|c|}
\hline & & \multicolumn{4}{|c|}{$\begin{array}{l}\text { 1: ERP support company falls far short of my } \\
\text { expectations in terms of that feature } \\
\text { 5: ERP support company greatly exceeds my } \\
\text { expectations in terms of that feature }\end{array}$} & \multirow[b]{2}{*}{5} \\
\hline \multirow[b]{2}{*}{ Dimensions } & & 1 & 2 & 3 & 4 & \\
\hline & Questions - Items & & & & & \\
\hline \multirow{5}{*}{ Reliability } & $\begin{array}{l}\text { a. I can count on the system to be "up" and available } \\
\text { when I need it. }\end{array}$ & 3.8 & 1.9 & 15.4 & 41.3 & 37.5 \\
\hline & & \multicolumn{2}{|c|}{$\alpha=5.7$} & & \multicolumn{2}{|c|}{$\beta=78.8$} \\
\hline & $\begin{array}{l}\text { b. The system is hardly ever subjected to unexpected or } \\
\text { inconvenient down times, which makes it harder to } \\
\text { do my work. }\end{array}$ & \multirow[t]{2}{*}{1} & 7.8 & 19.6 & 44.1 & 27.5 \\
\hline & & & $\alpha=8.8$ & & \multicolumn{2}{|c|}{$\beta=71.6$} \\
\hline & $\begin{array}{l}\text { c. The ERP system is hardly ever subject to frequent } \\
\text { system problems and crashes. }\end{array}$ & 3.9 & 8.8 & 11.8 & 32.4 & 43.1 \\
\hline \multirow{9}{*}{ Easy of use } & \multirow{3}{*}{$\begin{array}{l}\text { a. It is easy for me to remember how to perform tasks } \\
\text { using my company's ERP. }\end{array}$} & \multicolumn{2}{|c|}{$\alpha=12.7$} & & \multicolumn{2}{|c|}{$\beta=75.5$} \\
\hline & & 2 & 7.8 & 24.5 & 36.3 & 29.4 \\
\hline & & \multicolumn{2}{|c|}{$\alpha=9.8$} & & \multicolumn{2}{|c|}{$\beta=65.7$} \\
\hline & \multirow[t]{2}{*}{$\begin{array}{l}\text { b. I believe that it is easy to get my company's ERP to } \\
\text { do what I want it to do. }\end{array}$} & 2.9 & 10.7 & 24.3 & 40.8 & 21.4 \\
\hline & & \multicolumn{2}{|c|}{$\alpha=13.6$} & & \multicolumn{2}{|c|}{$\beta=62.2$} \\
\hline & \multirow[t]{2}{*}{$\begin{array}{l}\text { c. Overall, I believe that my company's ERP is easy to } \\
\text { use. }\end{array}$} & 1.9 & 10.7 & 24.3 & 40.8 & 22.3 \\
\hline & & \multicolumn{2}{|c|}{$\alpha=12.6$} & & \multicolumn{2}{|c|}{$\beta=63.1$} \\
\hline & \multirow[t]{2}{*}{$\begin{array}{l}\text { d. Learning to operate my company's ERP is easy to } \\
\text { use. }\end{array}$} & 2 & 8.8 & 15.7 & 45.1 & 28.4 \\
\hline & & \multicolumn{2}{|c|}{$\alpha=10.8$} & & \multicolumn{2}{|c|}{$\beta=73.5$} \\
\hline \multirow{4}{*}{ Integration } & $\begin{array}{l}\text { a. My company's ERP system is capable of } \\
\text { communication/ transmitting data between systems } \\
\text { servicing different functional areas. }\end{array}$ & 1 & 7 & 24 & 39 & 29 \\
\hline & & \multicolumn{2}{|c|}{$\alpha=8$} & & \multicolumn{2}{|c|}{$\beta=68$} \\
\hline & \multirow[t]{2}{*}{$\begin{array}{l}\text { b. My company's ERP system is compatible with } \\
\text { company's databases and operation systems. }\end{array}$} & 5 & 3 & 15.8 & 35.6 & 40.6 \\
\hline & & \multicolumn{2}{|c|}{$\alpha=8$} & & \multicolumn{2}{|c|}{$\beta=76.2$} \\
\hline
\end{tabular}

$\alpha=1+2, \beta=4+5$

With regard to the questions of service quality (Tables $8 \mathrm{a} \& 8 \mathrm{~b}$ ), the items of the dimension of assurance collect the most positive percentages (average amount of positive responses $73.43 \%$ ), while the objects of the dimension of responsiveness the least positive (average amount of positive responses $45.46 \%$ ). More generally, the employees of enterprises that support ERP systems are considered in great percentage to be polite (83.8\% positive responses), well-dressed ( $75 \%$ positive responses) and to inspire safety (69.3\% positive responses), while the enterprises of support appear to take into consideration the questions of the users (73.7\% positive responses).

On the other hand, it emerges that support companies do not provide their services at the times they promise to do so (positive responses $41 \%$ and negative $22.9 \%$ ), while they also do not inform users exactly when services will be performed ( $44.4 \%$ positive responses and $21.2 \%$ negative responses). More generally, a problem that concerns the lack of prompt services emerges (positive responses $49.5 \%$ and negative 19.2\%). 
Table 7: Information Quality (ERP Systems)

\begin{tabular}{|c|c|c|c|c|c|c|}
\hline & & $\begin{array}{r}\text { 1: ERP su } \\
\text { expec } \\
\text { 5: ERP su } \\
\text { expec }\end{array}$ & $\begin{array}{l}\text { omp } \\
\text { in ter } \\
\text { omp } \\
\text { in ter }\end{array}$ & $\begin{array}{l}\text { lls far } \\
\text { that } f \\
\text { eatly } \\
\text { that } f\end{array}$ & $\begin{array}{l}\text { tof my } \\
\text { eds my }\end{array}$ & \\
\hline & & 1 & 2 & 3 & 4 & 5 \\
\hline Dimensions & Questions - Items & & & & & \\
\hline & a. ERP system provides information availability. & 4.9 & 7.8 & 19.6 & 48 & 19.6 \\
\hline & & & & & & \\
\hline & b. ERP system provides information clarity. & 2.9 & 8.7 & 9.6 & 52.9 & 26 \\
\hline Content & & & & & & \\
\hline & c. ERP system provides information accuracy. & 3.8 & 6.7 & 6.7 & 51 & 31.7 \\
\hline & & & & & & \\
\hline & a. Do you get the information you need in time? & 2 & 6.9 & 23.5 & 40.2 & 27.5 \\
\hline Timoling & & & & & & \\
\hline Timeliness & b. Does the system provide up-to-date information? & 2.9 & 1.9 & 14.4 & 39.4 & 41.3 \\
\hline & & & & & & \\
\hline
\end{tabular}

Table 8a: Service Quality (ERP Systems)

\begin{tabular}{|c|c|c|c|c|c|c|}
\hline & & \multicolumn{4}{|c|}{$\begin{array}{l}\text { 1: ERP support company falls far short of my } \\
\text { expectations in terms of that feature } \\
\text { 5: ERP support company greatly exceeds my } \\
\text { expectations in terms of that feature }\end{array}$} & \multirow[b]{2}{*}{5} \\
\hline \multirow[b]{2}{*}{ Dimensions } & \multirow[b]{2}{*}{ Questions - Items } & 1 & 2 & 3 & 4 & \\
\hline & & & & & & \\
\hline \multirow{6}{*}{ Tangibles } & \multirow[t]{2}{*}{$\begin{array}{l}\text { a. ERP support company has up-to-date hardware } \\
\text { and software. }\end{array}$} & 5.5 & 6.6 & 34.1 & 40.7 & 13.2 \\
\hline & & \multicolumn{2}{|c|}{$\alpha=12.1$} & & \multicolumn{2}{|c|}{$\beta=53.9$} \\
\hline & $\begin{array}{l}\text { b. ERP support company's physical facilities are } \\
\text { visually appealing. }\end{array}$ & 4.8 & \multirow[t]{2}{*}{13.1} & \multirow[t]{2}{*}{19} & 42.9 & 20.2 \\
\hline & & $\alpha=17.9$ & & & \multicolumn{2}{|c|}{$\beta=63.1$} \\
\hline & \multirow{2}{*}{$\begin{array}{l}\text { c. ERP support company's employees are well } \\
\text { dressed and neat in appearance. }\end{array}$} & 2.1 & 9.4 & 13.5 & 51 & 24 \\
\hline & & \multicolumn{2}{|c|}{$\alpha=11.5$} & & \multicolumn{2}{|c|}{$\beta=75$} \\
\hline \multirow{5}{*}{ Reliability } & \multirow{2}{*}{$\begin{array}{l}\text { a. When users have a problem, ERP support } \\
\text { company shows a sincere interest in solving it. }\end{array}$} & 4 & 7.1 & 28.3 & 39.4 & 21.2 \\
\hline & & \multicolumn{2}{|c|}{$\alpha=11.1$} & & \multicolumn{2}{|c|}{$\beta=60.6$} \\
\hline & b. ERP support company is dependable. & 5 & $\alpha=12$ & 21 & \multicolumn{2}{|c|}{$\beta=67$} \\
\hline & \multirow[t]{2}{*}{$\begin{array}{l}\text { c. ERP support company provides its services at } \\
\text { the times it promises to do so. }\end{array}$} & 8.6 & 14.3 & 26.7 & 32.4 & 8.6 \\
\hline & & \multicolumn{2}{|c|}{$\alpha=22.9$} & & \multicolumn{2}{|c|}{$\beta=41$} \\
\hline \multirow{6}{*}{ Responsiveness } & \multirow[t]{2}{*}{$\begin{array}{l}\text { a. ERP support company tells users exactly when } \\
\text { services will be performed. }\end{array}$} & 11.1 & 10.1 & 34.3 & 34.3 & 10.1 \\
\hline & & \multicolumn{2}{|c|}{$\alpha=21.2$} & & \multicolumn{2}{|c|}{$\beta=44.4$} \\
\hline & \multirow[t]{2}{*}{$\begin{array}{l}\text { b. ERP support company employees give prompt } \\
\text { service to users. }\end{array}$} & 5.1 & 14.1 & 31.3 & 40.4 & 9.1 \\
\hline & & \multicolumn{2}{|c|}{$\alpha=19.2$} & & & \\
\hline & $\begin{array}{l}\text { c. ERP support company employees are always } \\
\text { willing to help users. }\end{array}$ & 6.9 & 29.9 & 20.7 & 19.5 & 23 \\
\hline & & & & & & \\
\hline
\end{tabular}

$\alpha=1+2, \beta=4+5$ 
Table 8b: Service Quality (ERP Systems)

\begin{tabular}{|c|c|c|c|c|c|c|}
\hline \multirow[b]{3}{*}{ Dimensions } & \multirow[b]{3}{*}{ Questions - Items } & \multicolumn{4}{|c|}{$\begin{array}{l}\text { 1: ERP support company falls far short of my } \\
\text { expectations in terms of that feature } \\
\text { 5: ERP support company greatly exceeds my } \\
\text { expectations in terms of that feature }\end{array}$} & \multirow{3}{*}{5} \\
\hline & & 1 & 2 & 3 & 4 & \\
\hline & & & & & & \\
\hline \multirow{5}{*}{ Assurance } & $\begin{array}{l}\text { a. The behavior of ERP support company employees } \\
\text { instills confidence in users. }\end{array}$ & 3.1 & 7.3 & 18.8 & 44.8 & 26 \\
\hline & & \multicolumn{2}{|c|}{$\alpha=10.4$} & & \multicolumn{2}{|c|}{$\beta=67.2$} \\
\hline & $\begin{array}{l}\text { b. Users will feel safe in their transactions with ERP } \\
\text { support company's employees. }\end{array}$ & 3.1 & 7.1 & 20.4 & 46.9 & 22.4 \\
\hline & & \multicolumn{2}{|c|}{$\alpha=10.2$} & & \multicolumn{2}{|c|}{$\beta=69.3$} \\
\hline & \multirow[t]{2}{*}{$\begin{array}{l}\text { c. ERP support company employees are consistently } \\
\text { courteous with users. }\end{array}$} & 1 & 2 & 13.1 & 49.5 & 34.3 \\
\hline \multirow{7}{*}{ Empathy } & & & & & & \\
\hline & \multirow{2}{*}{$\begin{array}{l}\text { a. ERP support company has employees who give } \\
\text { users personal attention. }\end{array}$} & 6.2 & 4.1 & 29.9 & 42.3 & 17.5 \\
\hline & & \multicolumn{2}{|c|}{$\alpha=10.3$} & & \multicolumn{2}{|c|}{$\beta=59.8$} \\
\hline & $\begin{array}{l}\text { b. ERP support company has the users' best interest at } \\
\text { heart. }\end{array}$ & 4 & 15.2 & 23.2 & 40.4 & 17.2 \\
\hline & \multirow{3}{*}{$\begin{array}{l}\text { c. ERP support company has the knowledge to answer } \\
\text { my questions }\end{array}$} & \multicolumn{2}{|c|}{$\alpha=19.2$} & & \multicolumn{2}{|c|}{$\beta=57.6$} \\
\hline & & 4 & 4 & 18.2 & 54.5 & 19.2 \\
\hline & & & & & \multicolumn{2}{|c|}{$\beta=73.7$} \\
\hline
\end{tabular}

$\alpha=1+2, \beta=4+5$

Despite the high percentage of positive answers on the ERP systems quality and the ERP systems quality of information, user opinions are not equally positive regarding their total satisfaction from the systems (average amount of positive responses $54.35 \%$ and of negatives $15.7 \%$, Table 9). It could be said that the answers of users are to a large extent concentrated in the center (30\%) comparatively to the above observation, in the remainder factors of success of ERP systems. This means that there exist important space for improvement of ERP systems but also of ERP systems services because, despite the high quality of individual elements (quality of systems, quality of information and quality of services), total satisfaction and total perception of quality appear to remain low.

Table 9: User Satisfaction

\begin{tabular}{|c|c|c|c|c|c|}
\hline & $\begin{array}{l}\text { 1: I tota } \\
5: \text { I tota }\end{array}$ & gree & & & \\
\hline & 1 & 2 & 3 & 4 & 5 \\
\hline \multicolumn{6}{|l|}{ Questions } \\
\hline \multirow[t]{2}{*}{$\begin{array}{l}\text { 1. My overall satisfaction level with regard to ERP support interface I } \\
\text { use is better than what I expected. }\end{array}$} & 3.8 & 9.5 & 33.3 & 41 & 12.4 \\
\hline & \multicolumn{2}{|c|}{$\alpha=13.3$} & & \multicolumn{2}{|c|}{$\beta=53.4$} \\
\hline \multirow[t]{2}{*}{$\begin{array}{l}\text { 2. The overall quality of the ERP support interface I use was better } \\
\text { than I thought it would be. }\end{array}$} & 2.9 & 15.2 & 26.7 & 44.8 & 10.5 \\
\hline & \multicolumn{2}{|c|}{$\alpha=18.1$} & & \multicolumn{2}{|c|}{$\beta=55.3$} \\
\hline
\end{tabular}


Finally, the net benefits from the use of ERP systems appear to be significant (Tables 10, 11). User perceptions, as much of the contribution of use of ERP systems in their individual productivity (average amount of positive responses $68 \%$ and negatives $9 \%$ ) as of its contribution to the management control of the enterprise (average amount of positive responses $67 \%$ and negatives $13 \%$ ), appear to be similar and to influence each other.

Table 10: Individual Productivity

\begin{tabular}{|c|c|c|c|c|c|}
\hline & \multicolumn{5}{|c|}{$\begin{array}{l}\text { 1: I totally disagree } \\
\text { 5: I totally agree }\end{array}$} \\
\hline & 1 & 2 & 3 & 4 & 5 \\
\hline \multicolumn{6}{|l|}{ Questions } \\
\hline \multirow[t]{2}{*}{$\begin{array}{l}\text { 1. ERP system allows me to accomplish more work than would } \\
\text { otherwise be possible. }\end{array}$} & 1 & 8.7 & 25.2 & 48.5 & 16.5 \\
\hline & \multicolumn{2}{|c|}{$\alpha=9.7$} & & \multicolumn{2}{|c|}{$\beta=65$} \\
\hline 2. ERP saves my time. & \multicolumn{2}{|c|}{$\alpha=8.8$} & 23.3 & \multicolumn{2}{|c|}{$\beta=67.9$} \\
\hline 3. ERP increases my productivity. & $\alpha=8.8$ & 7.8 & 20.6 & $\beta=70.6$ & $\begin{array}{l}20.6 \\
6\end{array}$ \\
\hline
\end{tabular}

Table 11: Management Control



$\alpha=1+2, \beta=4+5$

\section{Second Research Question}

As shown in Table 12, the Cronbach's Alpha results on the dimensions examined by the present study are all above .700 and, therefore considered to be very satisfactory.

Correlation analysis revealed the existence of many highly correlated factors, a fact that enhances the possibility of multicollinearity existing among the variables. One way to handle multicollinearity is to implement a stepwise regression analysis in order to determine the main regressors. For this reason and in order to test the hypothesis $\mathrm{H} 1$ to $\mathrm{H} 5$, four stepwise regression analyses have been implemented on all user responses $(\mathrm{N}=105)$, with user satisfaction being the regressand in the first regression, usage in the second, individual benefits in the third and organizational benefits in the fourth. 
Table 12: Reliability Results

\begin{tabular}{llcc}
\hline \multicolumn{1}{c}{ Measures } & \multicolumn{1}{c}{ Dimensions } & Items & Cronbach's Alpha \\
\hline \multirow{2}{*}{ ERP Service Quality } & a) Tangible & 2 & .799 \\
& b) Reliability \& Responsiveness & 3 & .883 \\
& c) Assurance & 2 & .851 \\
ERP Quality & d) Empathy & 3 & .837 \\
& a) Reliability & 3 & .871 \\
ERP Information Quality & b) Easy of Use & 3 & .898 \\
& c) Integration & 2 & .717 \\
Effectiveness & a) Content & 2 & .929 \\
& b) Timeliness & 2 & .854 \\
& a) Satisfaction & 2 & .898 \\
\end{tabular}

In the stepwise regression analysis that was implemented with user satisfaction being the regressand, it became apparent that all three quality factors (ERP system quality, ERP system information quality and ERP system services quality) are of statistical importance and may be used to forecast user satisfaction (Table 13). The significance of this model is demonstrated in the high value of $\mathrm{R}(.784)$, which reveals a strong relationship between the regressors and user satisfaction (regressand), while the study of $\mathrm{R}^{2}(.615)$ shows that $61.5 \%$ of user satisfaction deviation is explained by the model. The value of the statistical F importance is less than 0.001 (Sig. .000) which shows that the deviation explained by the model is not random. Thus hypothesis $\mathrm{H} 1$ is accepted.

Table 13: Predictors ERP Systems Quality, ERP Information Quality, ERP Services Quality And Dependent Variable: User Satisfaction

\begin{tabular}{|c|c|c|c|c|c|c|}
\hline Model & & $\begin{array}{r}\mathrm{Uns} \\
\mathrm{Cc}\end{array}$ & $\begin{array}{l}\text { ndardized } \\
\text { fficients }\end{array}$ & $\begin{array}{l}\text { Standardized } \\
\text { Coefficients }\end{array}$ & $\mathrm{t}$ & Sig. \\
\hline \multirow{5}{*}{3} & & B & Std. Error & Beta & & \\
\hline & (Constant) & -.005 & .310 & & -.015 & .988 \\
\hline & ERP Systems Quality & .444 & .109 & .410 & 4.082 & .000 \\
\hline & ERP Information Quality & .260 & .097 & .276 & 2.673 & .009 \\
\hline & ERP Services Quality & .208 & .088 & .206 & 2.377 & .020 \\
\hline
\end{tabular}

The stepwise regression analysis that was implemented with system usage being the regressand revealed that out of three quality factors (ERP system quality, information quality and quality of services), only ERP system quality constitutes a basic factor in predicting system use (Table 14). The present model does not appear able to predict the use of an ERP system to a great extent, since the value of $\mathrm{R}(.217)$ demonstrates a small relationship between the independent variable (ERP system quality) and usage of ERP system (dependent variable), while the study of $\mathrm{R}$ square (.047) shows that only $4.7 \%$ of system usage deviation is explained by the model. The value of the statistical $\mathrm{F}$ importance is less than 0.05 (Sig. .044) which shows that the deviation explained by the model is not random. Therefore, $\mathrm{H} 2 \mathrm{a}$ is accepted and $\mathrm{H} 2 \mathrm{~b}$ and $\mathrm{H} 2 \mathrm{c}$ are not supported. 
Table 14: Predictor: ERP System Quality And Dependent Variable: Frequency of Use

\begin{tabular}{|c|c|c|c|c|c|c|}
\hline \multirow[t]{2}{*}{ Model } & & \multicolumn{2}{|c|}{ Unstandardized Coefficients } & \multirow{2}{*}{$\begin{array}{c}\begin{array}{c}\text { Standardized } \\
\text { Coefficients }\end{array} \\
\text { Beta }\end{array}$} & \multirow[t]{2}{*}{$\mathrm{t}$} & \multirow[t]{2}{*}{ Sig. } \\
\hline & & B & Std. Error & & & \\
\hline \multirow[t]{2}{*}{1} & (Constant) & 3.873 & .911 & & 4.251 & .000 \\
\hline & ERP system quality & .469 & .229 & .217 & 2.049 & .044 \\
\hline
\end{tabular}

The variables of user satisfaction and usage of ERP system are positively correlated ( $R$ is 0.206 and $R$ squared .042), bound by a relationship that does not appear random as the ANOVA analysis shows $(\mathrm{P}<0.38)($ Table 15). The model predicts $4.2 \%$ of usage variable deviation. Thus hypothesis H3 is accepted.

Table 15: The Relationship Between User Satisfaction And Frequency Of Use

\begin{tabular}{ccccc}
\hline Model & $\mathrm{R}$ & R Square & Adjusted R Square & $\begin{array}{c}\text { Std. Error of the } \\
\text { Estimate }\end{array}$ \\
\hline 1 & $.206(\mathrm{a})$ & .042 & .033 & 1.766 \\
\hline
\end{tabular}

In the stepwise regression analysis implemented with individual benefits being the regressand, and usage of ERP system and user satisfaction being the independent variables, it became obvious that user satisfaction is the only predictor for individual benefits (and not the usage of ERP system) (Table 16). Even though the model only has one main predictor (user satisfaction), it appears to express a strong correlation between the user satisfaction and individual productivity factors ( $\mathrm{R}$ is 0.550 ) (Table 16). Moreover, from the ANOVA analysis it emerges that the relationship shown by the model is not random. In fact, the model can express $30.3 \%$ of individual productivity deviation, (R squared 0.303).

Table 16: Predictor: User Satisfaction And Dependent Variable: Individual Productivity

\begin{tabular}{clccccc}
\hline Model & & \multicolumn{2}{c}{ Unstandardized Coefficients } & $\begin{array}{c}\text { Standardized } \\
\text { Coefficients }\end{array}$ & t & Sig. \\
& & & Std. Error & Beta & & \\
\multirow{2}{*}{1} & (Constant) & 1.982 & .286 & & 6.921 & .000 \\
& User Satisfaction & .504 & .078 & .550 & 6.459 & .000 \\
\hline
\end{tabular}

In the stepwise regression analysis implemented with management control being the regressand, usage of ERP system and user satisfaction being the independent variables, it was shown that only user satisfaction is the basic factor of control management forecasting, and not system use (Table 17). Even though the model only has one main predictor (user satisfaction), it seems to express a strong correlation between the user satisfaction and control management factors ( $\mathrm{R}$ is 0.656 ). Moreover, from the ANOVA analysis it emerges that the relationship shown by the model is not random. In fact, the model can express $43 \%$ of control management deviation, (R squared 0.430 ). Thus hypothesis H5 is accepted, while hypothesis H4 is not. 
Table 17: Predictor: User Satisfaction And Dependent Variable: Management Control

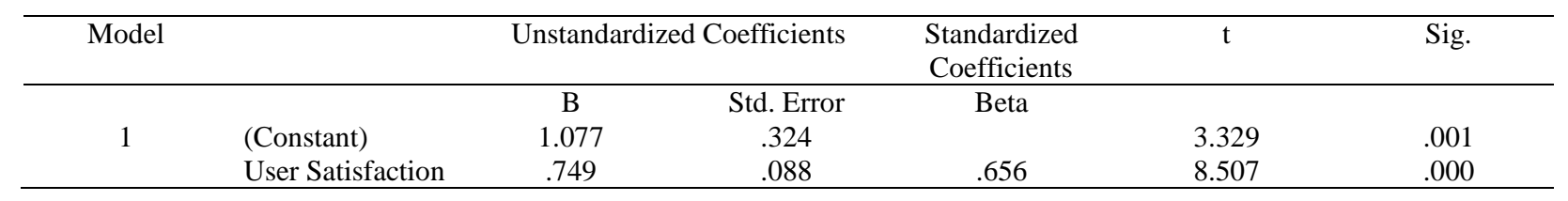

\section{CONCLUSIONS}

From the analysis, it emerges that not all hypotheses of the Delone and McLean model (2003) are met. The main problem encountered was that the factor of the usage of ERP system is not correlated with the rest information system factors of success, with the exception of the ERP system quality and user satisfaction factors. Considering that ERP system usage is in fact imposed on employees, it is easy to understand why it is not related with the rest of the factors.

The remaining Delone and McLean model (2003) has been evidenced to constitute a causal model. The dominating factors for the success of ERP systems (based on the D\&M model, 2003) are connected with positive correlation (except for the factor of usage, which is only correlated with user satisfaction and ERP system quality), a fact that demonstrates a cause and effect relationship. System quality factors (ERP system quality, ERP information quality and ERP services quality) are positively correlated with user satisfaction, which in turn is positively correlated with net benefits (individual and organizational benefits), though it is not related to the frequency of system usage. The emerging conclusion is that ERP system successful implementation is not an easy task, as ERP systems should entail quality in order to meet user satisfaction, which will ensure a more frequent system usage, individual (user) productivity and optimum management control by the company.

\section{IMPLICATIONS FOR INFORMATION SYSTEMS MARKETING STRATEGIES}

The study of the first research question reveals that Greek ERP support enterprises must focus on the provision of services. In particular, they should respond to the demands of their customers in a more prompt and organized way. It is also important for these companies to stick to their promises; ERP systems are operational systems and a slight delay in customer service can lead to substantial financial loss not only for customers but also for the service provider.

The analysis of the second research question reveals that the provision of low-quality services towards ERP users can have a negative impact on user satisfaction and individual productivity. Based on the D\&M model, this is due to the fact that the three main quality factors (ERP system quality, ERP system information quality and ERP systems services quality) are in direct relation to user satisfaction, which has a direct impact on individual productivity and management control.

A possible solution would be for the ERP support enterprises to use integrated CRM systems, in order to manage their customers more effectively. CRM systems contribute to Salesforce automation, Customer service and support, Field service and Marketing automation (Stefanou et al., 2003). In this way emerging problems encountered by the customers are forwarded to specialized staff who is assigned to resolve them. Problems are thus resolved effectively as soon as they emerge through a pro-drastic business policy. Moreover, mobile units assigned with the task to visit customers may offer personalized services, with the aid of CRM systems, resolving customer-user issues in a direct way.

Finally, the present research shows that ERP production and support companies should perceive ERP systems as a whole package of services and not as ordinary software. As far as ERP systems are concerned, software quality is not enough; it must be combined with information quality, service quality and individual and organizational benefits. 


\section{Propositions For Future Research}

The present work presented the descriptive and analytical statistics of a wider research effort in which the D\&M model (Delone and McLean, 1992, 2003) is the core. This work aims at examining the following research questions:

1. Are there any differences in responses between users who apply ERP systems for a small period and users who apply them for many years?

2. Are there any differences in the answers between users of ERP systems who have encountered intense problems in their use and users who have not encountered any problems?

3. Which are the strategies that can increase the satisfaction of users, their productivity, but also can improve the management of enterprises-purchasers?

\section{REFERENCES}

1. Bailey J.E. and S.W. Pearson (1983), Development of a tool for measuring and analysing computer user satisfaction, Management Science, 29(5), pp. 530 - 545.

2. Baroudi, J.J. and Orlikowski, W.J. (1988), A short-form measure of user information satisfaction: a psychometric evaluation and notes on use, Journal of Management Information Systems, 4(4), pp. 44-59.

3. Bingi P., M.K. Sharma, J.K. Godla (1999), Critical Issues Affecting an ERP Implementation, Information Systems Management, pp. 7-14.

4. Caruana A., L. Pitt (1997), INTQUAL - an internal measure of service quality and the link between service quality and business performance, European Journal of Marketing, 31(8), pp. $604-616$.

5. Chen, I.J. (2001), Planning for ERP systems: analysis and future trend, Business Process Management Journal 7(5), pp. 374-386.

6. CMU (1998) http://www.gsia.cmu.edu/bb26/70456/projects/sap/intro.htm.

7. Culnan, Mary J. (1983), Chauffeured Versus End User Access to Commercial Databases: The Effects of Task and Individual Differences, MIS Quarterly, 7(1), pp. 55-67.

8. Davenport T.H. (1998), Putting the enterprise into the enterprise system, Harvard Business Review 76(4), pp. 121-131.

9. Davis, Fred D. (1989), Perceived Usefulness, Perceived Ease of Use, and User Acceptance of Information Technology, MIS Quarterly, 13(3), pp. 319-340.

10. Delone W., E. McLean (1992), Information Systems Success: The Quest for the Dependent Variable, Information Systems Research 3(1), pp. 60-95.

11. Delone W., E. McLean (2003), The Delone and McLean Model of Information Systems Success: A TenYear Update, Journal of Management Information Systems 19(4), pp. 9-30.

12. Doll, William J., G. Torzadeh (1988), The Measure of End-User Computing Satisfaction, MIS Quarterly, 12(2), pp. 259-274.

13. Ein - Dor, P., E. Segev, Steinfeld A. (1981), Use of Management Information Systems: An empirical Study, Proceedings of the Second International Conference on Information Systems, pp. 215 - 228.

14. Everdingen Y.V., J.V. Hillegersberg, E. Waarts (2000), ERP adoption by European mid-size companies, Communications of the ACM, 43(4), pp. 27-31.

15. Fuerst W.L, P.H. Cheney (1995), Factors affecting the perceived utilization of computer - based Decision Support Systems, Decision Sciences, 13(4), pp.554 - 569.

16. Gelderman M. (1998), The relation between user satisfaction, usage of information systems, and performance,Information and Management, 34(1), 11 - 18.

17. Goodhue, D.L., and Thompson, R.L. (1995), Task-Technology Fit and Individual Performance, MIS Quarterly, June, 19(2): 213-233.

18. Gueutal, Hal G., N. Suprenant, K. Bubeck (1984), Effectively Utilizing Computer - Aided Design Technology: The role of Individual Difference Variables, Proceedings of the Fifth International Conference on Information Systems, pp. 21-30.

19. Guimaraes T., Igbaria M. (1997), Client/ server system success: Exploring the human side, Decision Sciences, 28(4), pp. $851-875$. 
20. Hogue J.T. (1987), A framework for the examination of Management involvement in Decision Support Systems, Journal of MIS, 4(1), pp. 96 - 100.

21. Igbaria M., Tan, M. (1997), The consequences of the information technology acceptance on subsequent individual performance, Infromation and Management, 32(3), 113- 121.

22. Igbaria, M., Iivari, J. \& Maragahh, H. (1995), Why do individuals use computer technology? A Finnish case study, Information and Management, 29, pp. 227-238.

23. Jun M., Z. Yang, D. Kim (2004), Customers' perceptions of online retailing service quality and their satisfaction, International Journal of Quality \& Reliability Management, 21(8), pp. 817-840.

24. Kahn B.K., D.M. Strong, R.Y. Wang (2002), Information Quality Benchmarks: Product and Service Performance, Communications of the Acm, 45(4).

25. Kang G., J. James (2004), Gronroos's Service quality dimensions: an examination of service quality model, Managing Service Quality 14(4), pp. 266-277.

26. Kim, Eunhong, Jinjoo Lee (1986), An Exploratory Contingency Model of User Participation and MIS Use, Information \& Management, 11(2), 87-97.

27. King, William R., Barry J. Epstein (1983), Assessing Information System Value, Decision Sciences, 14(1), pp. 34-45.

28. Klaus H., M. Rosemman, G. Gable (2000), What is ERP? Information Systems Frontiers 2(2), pp. 141-162.

29. Kremers M., H.V. Dissel (2000), ERP System Migrations. A provider's versus customer's perspective, Communication of the ACM 43(4), pp. 53-56.

30. Kumar K., J. Hillegersberg (2000), ERP Experiences and Evolution, Communications of the ACM 43(4), pp. 23-26.

31. Laudon K.C., J.P. Laudon (2001), Essentials of Management Information Systems, Fourth Edition, Prentice Hall.

32. Lee Z., J. Lee (2000), An ERP implementation case study from a knowledge transfer perspective, Journal of Information Technology 15, pp. 281-288.

33. Mahmood M.A., J. M. Burn, L. A. Gemoets, C. Jacquez (2000), Variables affecting information technology end-user satisfaction: a meta-analysis of the empirical literature, Int. J. Human-Computer Studies, 52, pp. 751-771.

34. Markus M.L., S. Axline, D. Petrie, C. Tanis (2000), Learning from adopters' experiences with ERP: problems encountered and success achieved, Journal of Information Technology 15, pp. 245-65.

35. Martin, M. (1998), Enterprise resource planning, Fortune, 137(2), pp. 149-51.

36. Miller, J., B.A. Doyle (1987), Measuring Effectiveness of Computer Based Information Systems in the Financial Services Sector, MIS Quarterly, 11(1), pp. 107-124.

37. Negash S., T. Ryanb, M. Igbaria (1987), Quality and effectiveness in Web-based customer support systems, Information \& Management 40, pp. 757-768.

38. Parasuraman, A., V. Zeithaml, L. Berry (1988), SERVQUAL: Multiple-item Scale for Measuring Consumer Perceptions of Service Quality, Journal of Retailing, 64, pp.12-40.

39. Pitt L.F., R.T. Watson, C.B. Kavan (1995), Service Quality: A Measure of Information Systems Effectiveness, MIS Quarterly 19, pp. 173-87.

40. Raymond, Louis (1985), Organizational Characteristics and MIS Success in the Context of Small Business, MIS Quarterly, 9(1), 37-52.

41. Rivard, Suzanne and Sid L. Huff (1984), User Developed Applications: Evaluation of Success from the DP Department Perspective, MIS Quarterly, 8(1), pp. 39-50.

42. Samoladas I., S. Bibi, I. Stamelos, G.L. Bleris (2003), Exploring the Quality of Free/Open Source Software: a Case Study on an ERP/CRM System, ${ }^{\text {th }}$ PanHellenic Conference in Informatics, Thessaloniki, Greece.

43. Sandoe, K., G. Corbitt, R. Boykin (2001), Enterprise Integration, John Wiley \& Sons, New York, NY.

44. Seddon P.B. (1997), A respecification and extension of the DeLone and McLean model of IS success, Information Systems Research 8(3), pp. 240-253.

45. Seddon P.B., M.Y. Kiew (1994), A partial test and development of the Delone and McLean model of IS Success, In J.I. Degross, S.L. Huff, and MC Munro (eds.), Proceedings of the International Conference on Information Systems, Atlanta, GA: Association for Information Systems, pp. $99-110$.

46. Shehab E.M., M.W. Sharp, L. Supramaniam, T.A. Spedding (2004), Enterprise Resource Planning - An integrative review, Business Process Management Journal 10(4), pp. 359-386. 
47. Siriginidi S.R. (2000), Enterprise resource planning in re-engineering business, Business Process Management Journal 6(5), pp. 376-391.

48. Sprott, D. (2000), Componentizing the enterprise application packages, Communications of the ACM, 43(4), pp. 63-69.

49. Srinivasan A. (1985), Alterative Measures of System Effectiveness: Associations and Implications, MIS Quarterly, 9(3), pp. $243-253$.

50. Strong D.M., Y.W. Lee, R.Y. Wang (1997), Data Quality in Context, Communications of the ACM 40(5), pp. 103-110.

51. Taylor S., Todd P. (1995), Understanding information technology usage: A test of competing models, Information Systems Research, 6(2), pp. 1328 - 1342.

52. Teng J., Calhoun K. (1996), Organizational computing as a facilitator of operational and managerial decision making: An exploratory study of managers' perceptions, Decision Sciences, 27(4), pp. $673-710$.

53. Torkzadeh G., W.J. Doll (1999), The development of a tool for measuring the perceived impact of information technology on work, Omega - The International Journal of Management Science, 27(3), pp. 327 $-339$.

54. Xu Y., D.C. Yen, B. Lin, D.C. Chou (2002), Adopting customer relationship management technology, Industrial Management \& Data Systems, 102(8), pp. 442-452.

55. Yang Z., X. Fang (2004), Online service quality dimensions and their relationships with satisfaction - A content analysis of customer reviews of securities brokerage services, International Journal of Service Industry Management, 15(3), pp. 302-326.

56. Yoon Y., T. Guimaraes, Q. O’Neal (1995), Exploring the factors associated with expert systems success, MIS Quarterly 19 (1), pp. 83-106.

57. Yuthas K., Young S.T. (1998), Material matters: Assessing the effectiveness of materials management IS, Information and Management, 33(3), pp. 115 - 124.

58. Zhang L., M. Lee, Z. Zhang, P. Banerjee (2002), Critical Success Factors of Enterprise Resource Planning Systems Implementation Success in China, Proceedings of the 36th Hawaii International Conference on System Sciences (HICSS’03).

Appendix

Figure 1: Delone And McLean's Model (2003)

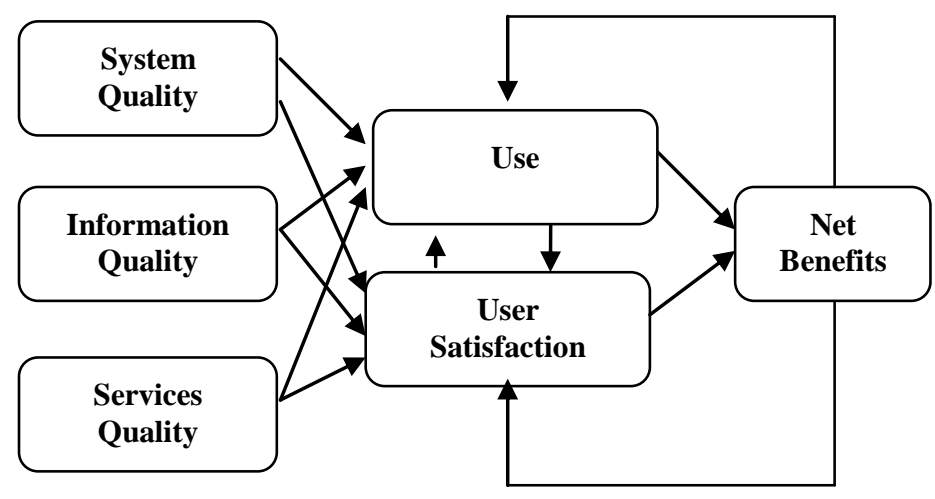

